THE GREAT WALL 



\title{
THE GREAT WALL
}

\author{
A Cultural History
}

CARLOS ROJAS

Harvard University Press

Cambridge, Massachusetts

London, England

2010 
Copyright (C) 2010 by the President and Fellows of Harvard College All rights reserved

\section{Library of Congress Cataloging-in-Publication Data}

Rojas, Carlos, 1970-

The Great Wall : a cultural history / Carlos Rojas.

$$
\text { p. } \mathrm{cm} \text {. }
$$

Includes bibliographical references and index.

ISBN-13: 978-0-674-04787-7 (alk. paper)

ISBN-10: 0-674-04787-7 (alk. paper)

1. Great Wall of China (China)-History.

2. China-Civilization.

I. Title.

DS793.G67R65 2010

951—dc22 2010024946 
For Eileen 
